внутрішніх факторів впливу на обсяги ватажних перевезень, на сучасному етапі діють і зовнішні фактори. Динаміка обсягів вантажних перевезень $є$ дзеркальним відображенням макроекономічних показників країни.

Основною причиною падіння обсягів вантажних перевезень є кризовий стан економіки й насамперед промисловості, що значною мірою зумовлено бойовими діями на сході країни, a також повязано із критичним станом інфраструктури та рухомого складу залізничного транспорту.

Більш детально i аргументовано автори даної статті приведуть результати досліджень щодо тенденції та факторів впливу на обсяг вантажних перевезень у сучасних умовах по всіх видах сполучень (імпорт, експорт, транзит, внутрішні перевезення ) у наступних виданнях.

\section{ПЕРЕЛІК ВИКОРИСТАНИХ ДЖЕРЕЛ}

1. Транспортна стратегія України на період до 2020 року [Електронній ресурс] // http://zakon2.rada.gov.ua/laws/show/2174$2010-\%$ D $1 \% 80$

2. Статистичний збірник. Транспорт i зв'язок. Державна служба
статистикиУкраїни.

К.:Держаналітінформ, 2017.

3.Собкевич O.В., Михайличенко К. М. / Механізми ефективного використання та розвитку потенціалу транспортнодорожнього комплексу України. - К.: НІСД, 2014. - 60 c.

4. Кірпа Г.М. Інтеграція залізничного транспорту України у європейську транспортну систему: монографія / Г.М. Кірпа. - Д. : Вид. - во Дніпропетр. нац. ун- ту залізн. трансп. ім. акад. В. Лазаряна, 2004. - 248c.

5. Колесникова Н.М. Адаптивногармонізаційний механізм ціноутворення на залізничному транспорті: формування, функціонування та розвиток: Монографія. К.: КУЕТТ, 2006. - 564 с.

6. Кулаєв Ю.Ф. Економіка залізничного транспорту: / Ю.Ф. Кулаєв. 2-е вид., переробл. і доповн. - К.: “Фенікс", 2012. -240 c.

7. Пасічник B.I. Управління економікою експлуатаційної роботи залізниць України: Навчальний посібник. К.: Основа, 2005. - 376 с.

8. Чорний В.В. Конкурентні переваги залізниць на ринку вантажних перевезень / В.В. Чорний // Вісн. Черніг. держ. технолог. ун-ту. Серія "Економічні науки". - 2012. - №1(56) . - С. 140 - 146.

УДК656.027(477)

\title{
ОСОБЛИВОСТІ СТВОРЕННЯ НА ЗАЛІЗНИЦЯХ УКРАЇНИ МЕРЕЖІ ШВИДКІСНИХ ЗАЛІЗНИЧНИХ МАГІСТРАЛЕЙ
}

\author{
Зайщева І.Ю., д.е.н., професор (УкрДУЗТ)
}

Майбутнє залізничного транспорту України пов'язане з реалізачією стратегічних рішень, серед яких реформування галузі та впровадження великомасштабних інноваційних проектів. Найбільш актуальною проблемою сьогодні $є$ організація швидкісного пасажсирського руху. 
У статті досліджено світовий досвід ефективного функиіонування залізничного транспорту. На цій основі запропоновано комплекс заходів щзодо підвищення ефрективності функиіонування вітчизняного залізничного транспорту в умовах впровадження на залізничях України мережі швидкісних залізничних магістралей.

Головним напрямом розвитку залізничного транспорту України є створення, а надалі й удосконалення швидкісних, а згодом і високошвидкісних магістралей. Це створить ряд конкурентні переваги не лише залізничного транспорту, а і всієї економіки краӥни внаслідок збільшення пасажирообігу.

Ключові слова: залізничний транспорт, транспортна система Украйни, реформування залізничної галузі, швидкісний пасажсирський рух, транс'європейська високошвидкісна залізнична мережс, високошвидкісне сполучення.

\title{
ОСОБЕННОСТИ СОЗДАНИЯ НА ЖЕЛЕЗНЫХ ДОРОГАХ УКРАИНЫ СЕТИ СКОРОСТНЫХ ЖЕЛЕЗНОДОРОЖНЫХ МАГИСТРАЛЕЙ
}

\author{
Зайцева И.Ю., д.э.н., профессор (УкрГУЖТ)
}

Будущее железнодорожного транспорта Украинь связано с реализащией стратегических решений, среди которых реформирование отрасли и внедрение крупномасштабных инновачионных проектов. Наиболее актуальной проблемой сегодня является организаџия скоростного пассажирского движения.

B статье исследовань мировой опьы эфффективного функционирования железнодорожного транспорта. На этой основе предложен комплекс мер по повышению эффективности функиионирования отечественного железнодорожного транспорта в условиях внедрения на железных дорогах Украины сети скоростных железнодорожных магистралей.

Ключевые слова: жжелезнодорожный транспорт, транспортная система Украины, реформирования железнодорожной отрасли, скоростное пассажирское движение, трансвевропейская высокоскоростная жкелезнодорожная сеть, высокоскоростное сообщение.

\section{FEATURES OF CREATION ON THE RAILWAY ROADS OF UKRAINE A NETWORK OF SPEED RAILWAY MAGISTRIES}

\author{
Zaitseva I., d.e.n., professor (Ukrainian State University of Railway Transport)
}

The future of Ukraine's rail transport is associated with the implementation of strategic decisions, including reforming the industry and implementing large-scale innovation projects. The most urgent problem today is the organization of high-speed passenger traffic. High-speed connectivity requires the full compatibility of the characteristics of rolling stock and the infrastructure of rail transport. Efficiency, safety, quality of operation, and operational costs depend on the compatibility of rolling stock and infrastructure, therefore this parameter is given special attention in the legislation of the European Union. The article examines the world experience of efficient operation of railway transport. On this basis, a set of measures aimed at improving the efficiency of domestic rail transport in the conditions of implementation of the

Вісник економіки транспорту і промисловості № 60, 2017 
network of high-speed railways on the railways of Ukraine is proposed. The main direction of the development of the railway transport of Ukraine is the creation and further development of high-speed and, subsequently, high-speed highways. This will create a number of competitive advantages not only for rail transport, but also for the entire economy of the country as a result of increased passenger traffic.

Key words: railway transport, transport system of Ukraine, railroad reform, highspeed passenger traffic, trans-European high-speed railway network, high-speed communication.

Постановка проблеми та іiі I. Корженевичем, М. Курганом, Ю. зв`язок 3 науковими чи практичними Барашем [7]; проаналізовано завданнями. Залізничний транспорт впровадження та розвиток швидкісних України $є$ однією 3 найважливіших пасажирських перевезень в Україні галузей виробничої інфраструктури (Ю.Бараш, О.Гненний, А.Момот [1]); національної економіки - основою проаналізовано напрями впровадження транспортної системи України. Майбутнє швидкісних пасажирських перевезень в залізничного транспорту України пов'язане 3 реалізацією стратегічних рішень, серед яких реформування галузі та впровадження великомасштабних інноваційних проектів. Найбільш актуальною сьогодні $\epsilon$ організація швидкісного пасажирського руху.

Аналіз останніх досліджень та виділення невирішених частин загальної проблеми. Аналіз останніх досліджень і результатів. Основи дослідження ефективності впровадження швидкісного руху на залізницях України закладено в праці Г. Кірпи [6]; комплексних результатів оцінювання ефективності впровадження швидкісного руху досягли М. Срьоміна та Ю. Пащенко [5,4]; профільне Міністерство розробило Концепцію Державної цільової програми впровадження на залізницях швидкісного руху вантажних поїздів. Цією Концепцією визначено основні засади розроблення Державної цільової програми впровадження на залізницях України мережі швидкісних залізничних магістралей для сполучення України 3 великими промисловими центрами, а також з країнами Західної Свропи та СНД; продовжено дослідження щодо визначення розмірів економії поточних витрат при впроваджені швидкісного руху Україні та їх недоліки Н.Божок [2].

Метою даної роботи с дослідження світового досвіду ефективного функціонування залізничного транспорту. На цій основі запропоновано комплекс заходів щодо підвищення ефективності функціонування вітчизняного залізничного транспорту в умовах впровадження на залізницях України мережі швидкісних залізничних магістралей.

Виклад основного матеріалу дослідження. Найбільш розповсюдженою в світі є колія 1435 мм, тому вона i називається «нормальною», і саме така колія використовується на залізницях практично усіх розвинених країн на усіх континентах. Перші залізниці на західних теренах України теж мали таку колію (до 1939 року). Залізниці 3 такою колією складають $60 \%$ протяжності усіх залізниць світу, тоді як колія 1520 мм - менше 17\%.

Для

середньостатистичного європейця на вибір виду транспорту впливає ціла низка чинників, найважливішим 3 яких є мета поїздки. У розподілі міжнародних залізничних поїздок за їх цільовою ознакою переважають приватні $(81,5 \%)$ поїздки, які $\epsilon$ більш інтенсивними, ніж ділові (18,5\%). Технологічні досягнення в галузі

Вісник економіки транспорту і промисловості № 60, 2017 
інфраструктури та рухомого складу залізничного транспорту дозволили істотно скоротити тривалість поїздки за маршрутами, які входять у мережу високошвидкісних залізничних сполучень, порівняно з тривалістю поїздки звичайним поїздом або автомобілем.

Тривалість поїздки $є$ одним 3 важливих чинників, що визначають попит на перевезення тим чи іншим видом пасажирського транспорту, іii зменшення внаслідок розвитку мережі високошвидкісних магістралей (ВШМ) зумовило значне зростання пасажиропотоків на цілій низці напрямків. Згідно 3 [1] тривалість поїздки після введення високошвидкісних сполучень на певних маршрутах скоротилася в 1,6-2,7 разу. При цьому переважним є скорочення відповідної тривалості в 1,6-1,9 разу (на $60 \%$ маршрутів). Слід зазначити, що тільки на $16 \%$ полігону залізниць Європейського Союзу, де експлуатуються високошвидкісні поїзди, вони працюють при повній реалізації закладених у них можливостей.

У той же час у Японії цей показник сягає 91\%. При цьому уявлення про високошвидкісний транспорт розрізняється як по країнах, так i за історичними періодами. На початку XXI ст. до високошвидкісних відносили поїзди, які здатні розвивати швидкість понад 150-160 км/год, а вже через 10 років на звичайних модернізованих лініях швидкість високошвидкісних поїздів становить понад 200 км/год (на спеціалізованих - понад 250-300 км/год). Швидкість поїздів, які належать до швидкісних, як правило, не перевищує 200 км/год. При Міжнародному союзі залізниць була створена цільова робоча група 3 високошвидкісного сполучення, завданням якої було роз'яснення поняття «високошвидкісне сполучення» 3 різних позицій: - інфраструктури; - рухомого складу; - експлуатації. Розроблено кілька визначень високошвидкісного руху, при цьому навмисно використано слово «поняття», оскільки немає єдиного визначення для «високошвидкісного залізничного сполучення». Визначення різняться залежно від критеріїв, що відображує складність розвитку високошвидкісної залізничної системи. Одне 3 понять «високошвидкісна лінія» надається Євросоюзом у Директиві 96/48/СC.

Відповідно до положень цієї Директиви до високошвидкісних належать нові лінії для руху 3 максимальною швидкістю 250 км/год і більше, реконструйовані діючі лінії для руху 3 максимальною швидкістю 200 км/год i реконструйовані лінії 3 обмеженнями швидкості за топографічними та іншими умовами. Згідно з Директивою 96/48/СС визначення «високошвидкісна залізниця» включає в себе кілька понять. Залізнична лінія називається «високошвидкісною лінією», якщо вона була спеціально побудована для руху по їздів зі швидкістю понад 250 км/год протягом усієї поїздки або, принаймні, більшої частини поїздки. Високошвидкісне сполучення за своєю суттю становить собою комбінацію різних компонентів, які формують одну систему.

До таких компонентів належать інфраструктура (нові лінії, які побудовані для руху зі швидкостями понад 250 км/год, і модернізовані лінії, на яких швидкість руху може становити 200- 220 км/год, на деяких із них експлуатуються поїзди з примусовим нахилом кузова в кривих), рухомий склад та умови експлуатації. Оскільки високошвидкісні поїзди можуть експлуатуватися на звичайній залізничній мережі, поняття «високошвидкісне сполучення» в деяких державах, у т. ч. й у Свропейському Союзі, часто використовується для позначення руху високошвидкісних поїздів звичайними лініями, але 3 більш низькими швидкостями, ніж дозволено

Вісник економіки транспорту і промисловості № 60, 2017 
для нової високошвидкісної залізничної інфраструктури. У додатку 1 Директиви 96/48/ЄС високошвидкісний рух розглядається як сукупність високошвидкісної інфраструктури, рухомого складу й високошвидкісних ліній.

Що стосується інфраструктури, то до неї включають високошвидкісні лінії транс'європейської високошвидкісної залізничної мережі. Зокрема, інфраструктуру, спеціально побудовану для високошвидкісного сполучення, інфраструктуру, яка була модернізована 3 метою організації на ній високошвидкісного сполучення. До неї можуть належати лінії, які прилягають, зокрема новозбудовані або модернізовані лінії для високошвидкісного сполучення, що ведуть до центральних станцій міст, де швидкість руху обмежена місцевими умовами.

Високошвидкісне

сполучення вимагає повної сумісності характеристик рухомого складу та інфраструктури залізничного транспорту. Ефективність, безпечність, якість експлуатації, а також експлуатаційні витрати залежать від сумісності рухомого складу та інфраструктури, тому цьому параметру приділяється особлива увага в законодавстві Свропейського Союзу.

Міжнародний союз залізниць виділяе чотири типи систем високошвидкісного сполучення:

1. Класична система високошвидкісного сполучення, до якої входять високошвидкісні лінії та високошвидкісні поїзди, які не експлуатуються на інших лініях (японська залізнична система «Сінкансен»).

2. Мережа високошвидкісних ліній, на яких експлуатуються високошвидкісні поїзди, які можуть експлуатуватись і на звичайних лініях (залізнична система Франції, де високошвидкісні поїзди експлуатуються також на звичайній мережі залізниць).

3.На високошвидкісних лініях експлуатуються не тільки високошвид кісні поїзди, швидкість яких понад 250 км/год, але й звичайні поїзди, які обладнані системою переходу 3 однієї ширини колії на іншу. Через більш низькі швидкості руху звичайних поїздів пропускна спроможність високошвидкісних ліній знижується. 3 іншого боку, високошвидкісні поїзди не експлуатуються на звичайних лініях (залізнична система Іспанії AVE).

4. На високошвидкісних лініях можуть експлуатуватися у т. ч. і звичайні поїзди, а на звичайних лініях високошвидкісні поїзди (залізничні системи Італії та Німеччини).

Кардинальні зміни політичного клімату в Західній Європі наприкінці XX ст. дали новий поштовх розвитку ідеї високошвидкісних залізничних сполучень. Пропозиція Європейської комісії 1990 року щодо високошвидкісної мережі $\epsilon$ відправною точкою для процесу планування іiі розвитку. Iз XX ст. розвиваються ВШМ i в країнах Азії. Аналіз даних щодо існуючих ВШМ Свразії показав їх значний розкид за довжиною. Так, $31 \%$ країн, які розглянуто, мають довжину ВШМ до 250 км, а 23\% до 500 км. При цьому довжина ВШМ Китаю в 180 разів перевищує їх довжину в Швейцарії. У понад 38\% країн нові ВШМ не будуються, у $23 \%$ передбачено будівництво до 250 км таких ліній і в $15 \%$ - до 500 км. Загальна довжина ВШМ складає 16804 км, з яких 39,5\% припадає на країни Західної Свропи, а 60,5\% - на країни Азії (переважно за рахунок Китаю). Максимальна швидкість руху високошвидкісних поїздів, які використовуються в країнах Західної Європи, змінюється в досить широкому діапазоні від 210 до 350 км/год. Тобто

Вісник економіки транспорту і промисловості № 60, 2017 
швидкість поїзда AVE S102 в 1,7 разу перевищує швидкість поїзда X2000 [9].

При цьому найбільш поширеною $\epsilon$ максимальна швидкість руху, що знаходиться в діапазоні 251-300 км/год, яка характерна майже для 47\% поїздів. Поїзди, які використовуються на ВШМ Західної Свропи, відрізняються не лише максимальною швидкістю руху, але й конфігурацією та загальною кількістю вагонів, яка може змінюватися в діапазоні від трьох до шістнадцяти вагонів. Максимальна кількість пасажирів у поїзді змінюється в діапазоні 160-685 (різниця становить 525 пасажирів, або 4,3 разу), довжина поїзда змінюється в діапазоні 81,2-358 м (різниця становить майже 277 м, або 4,4 разу), а його маса змінюється в діапазоні 152,5-795 т (різниця становить майже 643 т, або 5,2 разу) [9]. Як показує практика, не в усіх випадках має місце зв'язок між кількістю вагонів у високошвидкісному поїзді та максимальною кількістю пасажирів у поїзді, його довжиною та масою, тобто не завжди збільшення кількості вагонів приводить до відповідного збільшення вказаних вище показників.

Найбільш логічним, правильним i радикальним способом забезпечення повної інтероперабельності залізничної системи України з основними та найбільш розвиненими залізницями світу був би поступовий перехід іiі залізниць на колію 1435 мм - як шляхом будівництва нових високошвидкісних ліній, так і «перешивки» колії 1520 мм на ширину 1435 мм або улаштування суміщеної колії 1435мм/1520мм. Доцільно розпочати нове будівництво двоколійної високошвидкісної магістралі - залізниці 1435 мм (ВШМ 1435) на напрямку Одеса Київ - Львів - Мостиська-2 (кордон України та СС) - Медика (Польща). У подальшому ВШМ 1435 слід від Києва продовжити на Харків та Дніпро, а після звільнення Донбасу з'єднати ці міста 3 Донецьком та Луганськом.

Нові високошвидкісні залізниці України колії 1435 мм - це не фантастичний «прожект», а цілком реальний бізнес-проект, який дає Україні в перспективі багато переваг, а саме:

1. Здійсниться реальна євроінтеграція, безперешкодний залізничний зв'язок з Свросоюзом в єдиній колії 1435 мм, що втілює остаточно нову геополітичну орієнтацію України та іiі повернення в Свропу.

2. Будівництво та експлуатація нових найсучасніших ліній 1435 мм принесе в Україну нові технології та створить робочі місця 3 достойною оплатою, підвищить платоспроможність населення.

3. Залізниці отримають можливість здійснювати по нових лініях швидкісні перевезення вантажів, що потребують прискореної доставки - передусім контейнерних, а також інших вантажів мультимодального транспорту, що матиме позитивні економічні, екологічні та соціальні наслідки.

4. Зросте мобільність населення в національному та міжнародному масштабі, гасло Майданів «Схід і Захід разом!» нарешті втілиться в життя, буде забезпечена якісна транспортна підтримка безвізового режиму.

5. Оживиться бізнес, ринок праці та житлового будівництва навколо нових високошвидкісних ліній колії 1435 мм, зросте податкова база усіх бюджетів. 6. Обороноздатність та територіальна цілісність України будуть забезпечені на якісно вищому рівні.

Фінансові ресурси, необхідні на здійснення проекту «ВШМ 1435» колосальні, хоча вони у 3-7 разів менші, ніж ті, що вже спрямовує Росія на свою ВСМ «Москва - Пекін» (245 млр. дол США). Якщо не знайти та вкласти ці ресурси у транспортні проекти

Вісник економіки транспорту і промисловості № 60, 2017 
національного та міжнародного масштабу, рівня проекту «ВШМ 1435» - Україна може зникнути з транспортної мапи світу - і це не метафора. Проект «ВШМ 1435» чудово укладається у НТС-2030, зокрема, у такі іiі складові: задачі експлуатації, регулювання та ліцензування: мультимодальний транспорт.

Необхідно залучити транзитний транспорт шляхом визначення ролей окремих видів транспорту 3 метою підвищення ефективності роботи системи в цілому. Регіональні/політичні задачі: транспортна політика повинна забезпечити територіальну цілісність шляхом забезпечення доступу та транспортного сполучення усіх регіонів. Операційні та/або організаційні перешкоди на кордонах, зазвичай, подовжують час перевезень та знижують середню швидкість руху, що позначається на привабливості маршруту з точки зору здійснення міжнародних перевезень. Усунення перешкод на кордонах $\epsilon$ окремим викликом для України.

Пріоритетний напрям 2: надання якісних та ефективних послуг перевезень. Впровадження інтегрованих транспортних систем, які задовольнятимуть вимоги користувачів завдяки підвищенню економічних переваг використання існуючих основних засобів. Застосування нових технологій 3 метою підвищення ефективності перевезень. Пріоритизація належного утримання основних засобів над новими інвестиціями. Підвищення енергоефективності та впровадження політики захисту довкілля. Усунення існуючих бар'єрів у сфері логістики та мультимодального транспорту в межах національних коридорів, інтеграція до ТЄМ-Т та покращення умов транзиту [3].

Сьогодні Китай відмовився від ідеї повсюдного будівництва високошвидкісних магістралей і залучив нову стратегію на період до 2015 року, спрямовану на розвиток магістралей із різною швидкістю руху. Незважаючи на комфортабельність високошвидкісних експресів, вони виявляються недоступними для великої категорії людей 3 низьким рівнем доходів. На відносно коротких маршрутах перевага високошвидкісних поїздів зовсім нівелюється високою вартістю проїзду. Поява поїздів з різними швидкостями руху дасть змогу пасажирам купувати дешевші квитки на “повільні" потяги, а також збільшить кількість зупинок [8].

Висновки. Розглядаючи світовий досвід для підвищення ефективності функціонування українського залізничного транспорту, сьогодні потрібно:

1. Розвивати прискорений рух (до 160 км/год) на основі наявних шляхів.

2. Підвищити швидкість руху пасажирських поїздів до 200 км/год, для чого необхідно технічно переоснастити колійне господарство 3 подальшою механізацією його технологічних процесів.

3.

Впроваджувати високошвидкісний рух, для чого потрібно побудовати окрему нову колію, яка передбачає можливість руху пасажирських поїздів зі швидкістю 200350 км/год. Для цього мають бути задіяні потужності як підприємств залізничного транспорту, так і сторонніх організацій.

4. Розділити вантажні і пасажирські потоки.

Для

підвищення конкурентоспроможності швидкісних поїздів “ІНТЕРСІТІ+" необхідно:

1. Зниження терміну подорожі; Lviv Polytechnic National University Institutional Repository http://ena.lp.edu.ua 476

2. Оптимізування графіка руху швидкісних поїздів;

3. Розширення мережі швидкісних магістралей по всій території України;

Вісник економіки транспорту і промисловості № 60, 2017 
4. Оптимізування величини тарифів 3 метою залучення до швидкісних перевезень додаткових пасажирів.

5.

Впровадження

високошвидкісного руху на території України. Головним напрямом розвитку залізничного транспорту України $\epsilon$ створення, а надалі й удосконалення швидкісних, а згодом і високошвидкісних магістралей. Це створить ряд конкурентні переваги не лише залізничного транспорту, а i всієї економіки країни внаслідок збільшення пасажирообігу.

\section{ПЕРЕЛІК ВИКОРИСТАНИХ ДЖЕРЕЛ}

1. Бараш Ю.С. Аналіз роботи швидкісного руху в Україні / Ю.С. Бараш, O.М. Гненний, А.В. Момот // Залізничний транспорт - $2014-$ С. 53-62.

2. Божок Н.О. Напрямки впровадження швидкісних пасажирських перевезень в Україні / Н.О. Божок // Збірник накових праць Дніпропетровського національного університету залізничного транспорту імені академіка В. Лазаряна "Проблеми економіки транспорту”. - 2013 - Вип. 5 С. 46-56.

3. Зайцева І.Ю. Аналіз фінансовоправових відносин в процесі інтеграції України до Транс-Свропейської транспортної мережі ТЕМ-Т[Текст] / I.Ю. Зайцева// Сучасні тенденції управління розвитком організаційно-економічних систем (новий погляд): колективна монографія / Заг. ред. д.е.н., професора Р.Р. Тіміргалєєвої. - Сімферополь: ВД "АРІАЛ", 2014. - с.473-483.

4. Єрьоміна М.О. Перерозподіл постійних витрат при розподілі вантажного та пасажирського руху за умов впровадження швидкісних та високошвидкісних залізничних перевезень в Україні / М.О.Срьоміна // Вісник економіки транспорту і промисловості. 2011. - №34. - C. 173-178

5. Інтегральна ефективність швидкісних залізничних магістралей: монографія / [Ю.С.Пащенко, М. Ю. Гончаров, Й. М. Кранц, В.О.Пилипчик та ін.]; за ред. С. І. Дорогунцова. - К.:РВПС України НАН України, 2005. - 266 с.; Концепція Державної цільової програми впровадження на залізницях швидкісного руху пасажирських поїздів на 2005-2015 pp. [Електронний ресурс] / Розпорядження Кабінету Міністрів України від 31 грудня 2004 p. No 979p - Режим доступу: http://zakon2.rada.gov.ua/laws/ show/9792004-p.;

6. Кірпа Г. Інтеграція залізничного транспорту України в Європейську транспортну систему: [монографія] /Георгій Кірпа. -Дніпропетровськ: ДНУЗТ, 2004. - 248 с.

7. Курган М.Б. Вплив підвищення швидкості поїздів на витрати, пов'язані із зносом колійної інфраструктури /М.Б. Курган.Д.М. Корженевич, Ю.С. Бараш //Вісник Дніпропетровського національного університету залізничного транспорту. - 2008. -№ 21. - С. 233-239.

8. Сазанов С.Л. Динамичное развитие высокоскоростных железных дорог Китая / С.Л.Сазанов.// Экономика железных дорог 2011-№ 8, С.82-92.

9. Шерстобитов А.С. Мировой опыт организации скоростного железнодорожного пассажирского сообщения [Електоронный ресрс] - Режим доступа - http://www.sworld.com.ua /konfer35/446.pdf 